\title{
COMUNICAÇÃO
}

\section{ESTÍMULO DO COMPORTAMENTO FOTOAUTOTRÓFICO DURANTE O ENRAIZAMENTO IN VITRO DE Annona glabra L. , II. ASPECTOS DA ANATOMIA DA FOLHA ANTES DA ACLIMATIZAÇÃO}

\author{
Stimulus of the photoautotrophic behavior during the in vitro rooting of Annona glabra L. , II. \\ Aspects of leaf anatomy before acclimatization
}

\author{
José Raniere Ferreira de Santana ${ }^{1}$, Renato Paiva ${ }^{2}$, Rodrigo Kelson Silva Resende ${ }^{3}$, Evaristo Mauro de Castro ${ }^{2}$, \\ Flávia Dionísio Pereira ${ }^{4}$, Lenaldo Moniz Oliveira ${ }^{1}$
}

\begin{abstract}
RESUMO
A baixa sobrevivência durante a aclimatização de plantas regeneradas através da micropropagação tem sido atribuída, entre vários fatores, à baixa capacidade fotossintética. O desenvolvimento de protocolos que utilizem sistemas de cultivo in vitro fotoautotróficos surgem como possibilidades potenciais para aumentar a eficiência da micropropagação. Objetivou-se, neste trabalho comparar as medições dos tecidos foliares de plantas de Annona glabra L. cultivadas in vitro, sob condições de estímulo ao fotoautotrofismo e heterotróficas, durante a fase de enraizamento, com plantas ex vitro (mantidas sob radiação fotossintética ativa de 130-170 $\mu \mathrm{mol} \cdot \mathrm{m}^{-2} \cdot \mathrm{s}^{-1}$, sem controle de temperatura). As brotações foram enraizadas em condições de estímulo ao fotoautotrofismo (meio sem sacarose e com aeração) e em condições heterotróficas (meio com sacarose e sem aeração). O meio de cultivo utilizado foi

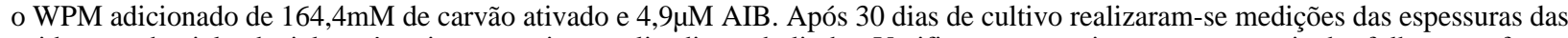
epidermes abaxial, adaxial, parênquima esponjoso, paliçadico e do limbo. Verificaram-se variações na anatomia das folhas, que foram caracterizadas por um aumento na espessura foliar de acordo com a aeração estabelecida. O enraizamento de plantas de $A$. glabra em condições de estímulo ao fotoautotrofismo permitiu desenvolvimento anátomo-fisiológico semelhante àquele observado em condições ex vitro, o que pode minimizar as perdas no processo de micropropagação.
\end{abstract}

Termos para indexação: Cultura de tecidos, rustificação, redução de custos, Annona glabra.

\begin{abstract}
The low survival during the acclimatization of plants regenerated through the micropropagation has been attributed, among several factors, to low the photosynthetic capacity. The development of photoautotrophic in vitro culture systems appears as potential possibilities of increasing the efficiency of the micropropagation. The aim of this work was to compare the leaf anatomy of plants of Annona glabra L. cultivated in vitro, under photoautotrophic and heterotrophic conditions, during the phase of rooting, with ex vitro (maintained in greenhouse under photosynthetic acitve radiation of $130-170 \mu \mathrm{mol} \cdot \mathrm{m}^{-2} \cdot \mathrm{s}^{-1}$, without control of room temperature). Shoots were rooted in photoautotrophic conditions (sucrose-free medium with aeration) heterotrophic conditions (medium with sucrose without ventilation). The medium of culture was the WPM supplied of $164.4 \mathrm{mM}$ of activated charcoal and $4.9 \mu \mathrm{M}$ AIB. After 30 days of culture measurements of the foliar thickness of the epidermises abaxial, adaxial, parenchyma spongy, palisade and limb one. Verified variations in the anatomy of the leaves, that had been characterized by an increase in the leaf thickness in accordance with the established aeration. In vitro photoautotrophic rooting of plants Annona glabra L stimulated an anatomical and physiological development similar to the one observed in an ex vitro condition, which may minimize the losses at the acclimatization process.
\end{abstract}

Index terms: Tissue culture, harding, cost reduction, Annona glabra.

(Recebido em 2 de fevereiro de 2007 e aprovado em 8 de junho de 2007)

Tradicionalmente, utilizam-se na cultura de tecidos, recipientes fechados com as plantas crescendo sobre meio solidificado com ágar e suplementados com uma fonte de carbono. A sacarose é a fonte de carbono mais utilizado na cultura de tecidos e ela é incorporada ao meio de cultivo para facilitar o crescimento. As concentrações de sacarose, normalmente utilizadas, podem inibir a síntese de clorofila e com isso as plantas não desenvolvem capacidade fotoautotrófica, podendo causar crescimento reduzido e morte de mudas durante a fase de aclimatação (GEORGE \&

\footnotetext{
'Doutores - Departamento de Biologia/DBIO - Laboratório de Cultura de Tecidos - Unidade Experimental Horto Florestal - Universidade Estadual de Feira de Santana/UEFS - Avenida Presidente Dutra, s/n - Santa Mônica - 44055-000 - Feira de Santana, BA - raniere@uefs.br; lenaldo@ufes.br ${ }^{2}$ Doutores - Departamento de Biologia/DBI - Universidade Federal de Lavras/UFLA - Cx. P. 3037 - 37200-000 - Lavras, MG - renpaiva@ufla.br; emcastro@ufla.br

${ }^{3}$ Mestre - Departamento de Biologia/DBI - Universidade Federal de Lavras/UFLA - Cx. P. 3037 - 37200-000 - Lavras, MG - rkelsonrsr@yahoo.com.br ${ }^{4}$ Doutora - Departamento de Biologia/DBIO - Laboratório de Cultura de Tecidos - Unidade Experimental Horto Florestal - Universidade Estadual de Feira de Santana/UEFS - Avenida Presidente Dutra, s/n - Santa Mônica - 44055-000 - Feira de Santana, BA - flavia1808@hotmail.com - Bolsista FAPESB
} 
SHERRINGTON, 1984; KOZAI, 1991). Portanto, é consenso que se busque maior performance das plantas cultivadas in vitro, tornando o ambiente mais próximo das condições em que as elas crescem in vivo, aumentando assim a taxa de sobrevivência.

Uma possibilidade seria estimular a fotoautotrofia através da redução ou eliminação de carboidrato do meio e o aumento da aeração das culturas. Alguns autores têm alcançado êxito em seus estudos (CALVETE et al., 2002; FUENTES et al., 2005; HARARIKA, 2003; LEITE et al., 2000; SKREBSKY et al., 2006), considerando esses aspectos.

Outro fator importante envolvido na aclimatização é o enraizamento in vitro. Gribaudo \& Fronda (1993) sugerem adotar na última fase da cultura in vitro a diminuição da concentração de sacarose, com o intuito de promover a fotossíntese e habituar a planta à nutrição autotrófica.

No enraizamento fotoautotrófico, as mudanças ocorridas nas condições de cultivo são capazes de determinar a plasticidade adaptativa das plantas, favorecendo o processo e, conseqüentemente, originando plantas anátomo-fisiológicas mais adaptadas ao processo de aclimatização. Comparativamente, as plantas desenvolvidas heterotroficamente, em geral, apresentamse pouco lignificadas, com células de parede pouco espessadas, com abundância de espaços intercelulares, sistema vascular pouco desenvolvido e reduzida quantidade de tecidos de sustentação, sujeitos a desordens morfológicas e fisiológicas. Portanto, em geral, a anatomia interna e a ultra-estrutura são, diferentes daquelas crescidas fotoautroficamente, em casa de vegetação ou em campo (DONNELLY et al., 1985; KOZAI \& KITAYA, 1995; WETZSTEIN et al., 1981;ZIV, 1986).

Objetivou-se nesse trabalho comparar as medições dos tecidos foliares de plantas de Annona glabra. cultivadas in vitro, sob condições de estímulo ao fotoautotrofismo e heterotrofismo, durante a fase de enraizamento, com plantas mantidas ex vitro.

Para o estudo da anatomia foliar utilizaram-se brotações de Annona glabra L., com comprimento de $20 \mathrm{~mm}$ contendo pelo menos um par de folhas expandidas. Essas brotações foram enraizadas em condições fotoautotróficas e heterotróficas. Posteriormente, compararam-se essas plantas com aquelas mantidas ex vitro.

As plantas ex vitro, utilizadas para as medições anatômicas, tinham aproximadamente 3 anos e estavam mantidas em casa de vegetação com radiação fotossintética ativa de 130-170 $\mu$ mol. $\mathrm{m}^{-2}$. $\mathrm{s}^{-1}$, sem controle de temperatura.

\section{Cultivo com estímulo ao fotoautotrofismo}

As brotações foram enraizadas em $20 \mathrm{~mL}$ de meio de cultura WPM solidificado com $0,70 \%$ de ágar, sem sacarose, $164,4 \mathrm{mM}$ de carvão ativado e $4,9 \mu \mathrm{M}$ AIB, inoculadas em tubos de ensaio $(25 \times 150 \mathrm{~mm})$ fechados com tampa plástica, sem o uso da película de PVC. O pH do meio de cultura foi ajustado para 5,7 antes da autoclavagem e os tubos foram mantidos em sala de crescimento sob radiação fotossintética ativa de $45-55 \mu \mathrm{mol} . \mathrm{m}^{-2}$. $\mathrm{s}^{-1}$, a uma temperatura de $25 \pm 2^{\circ} \mathrm{C}$.

\section{Cultivo com estímulo ao heterotrofismo}

As brotações foram enraizadas nas mesmas condições descritas anteriormente, porém, os tubos de ensaio continham $10 \mathrm{~mL}$ de meio de cultura WPM suplementado com $87,64 \mathrm{mM}$ de sacarose e foram fechados com película de PVC.

\section{Estudo anatômico}

Após 30 dias de cultivo in vitro selecionaram-se quatro plantas de cada tratamento e retirou-se a primeira folha expandida, formada durante o enraizamento, onde foram extraídas seções de $0,5 \mathrm{~cm}^{2}$, em sua região mediana, e efetuados estudos anatômicos, com base no exame microscópico de cortes transversais obtidos à mão livre. As seções foram clarificadas em solução a $50 \%$ de hipoclorito de sódio, e em seguida, lavadas em água destilada, neutralizadas em água acética 1:500 e montadas em glicerina a $50 \%$. O corante usado foi a mistura azul de astra-safranina, conforme metodologia descrita por Bukastsh (1972).

Nos cortes transversais foram realizadas medições das espessuras das epidermes abaxial e adaxial, parênquima esponjoso e paliçádico e do limbo.

As medições foram realizadas utilizando-se ocular micrometrada aferida com lâmina, em seis cortes por repetições sendo utilizados três tratamentos, com quatro repetições. A média desses valores foi submetida à análise de variância e à teste de médias Tukey, a $5 \%$ de probabilidade. Todas as medições e contagens foram realizadas em microscópio OLYMPUS, modelo BX-60 e o programa utilizado para análise dos dados foi o software SISVAR (FERREIRA, 2003).

O tipo de cultivo foi significativo para todas as variáveis estudadas e, tanto no tratamento onde as plântulas foram cultivadas fototróficamente, quanto heterotróficamente enraizaram sem a formação de calos, deram origem a raízes adventícias, produziram plantas bem 
formadas, vigorosas, apresentando as mesmas características das plantas matrizes. Visivelmente, podese notar que as raízes das plantas provenientes do cultivo fotoautotrófico eram maiores, possuíam raízes secundárias e estavam em maior número, o que possivelmente possa determinar boa performance após o plantio no campo.

Um eficiente sistema de enraizamento deve apresentar alta porcentagem de brotos enraizados e sistema radicular de alta qualidade com a formação de número e comprimento de raízes adequadas e a ausência da formação de calo (KLERK et al., 1997; MOHAMMED \& VIVALDER, 1990).

O sistema de cultivo de estímulo ao fotoautotrofismo induziu a formação de uma epiderme mais espessa na face adaxial, quando comparado com os demais sistemas. Plantas ex vitro apresentaram espessura de $25,44 \mu \mathrm{m}$, as do cultivo com sacarose $25,52 \mu \mathrm{m}$ e as sem sacarose e sem vedação $31,20 \mu \mathrm{m}$. Na face abaxial, as plantas cultivadas no sistema sem sacarose e sem vedação e as $e x$ vitro mostraram o mesmo comportamento tendo epiderme com espessuras de 21,44 e 20,44 $\mu \mathrm{m}$ respectivamente. Os piores resultados para a espessura da epiderme abaxial foram aqueles obtidos pelo sistema de cultivo heterotrófico $(17,52 \mu \mathrm{m})$ (Figura 1A).

Quanto à espessura do mesofilo e do limbo foliar esses também foram significativamente maiores nas brotações submetidas ao cultivo sem sacarose e sem vedação, quando comparado com o cultivo com sacarose e com vedação. Em termos porcentuais, o ganho na espessura do mesofilo e no limbo, na condição sem sacarose e sem vedação, foi de 35,59 e 33,50\%, respectivamente. No sistema sem sacarose e sem vedação, o parênquima paliçadico e esponjoso atingiram a espessura de 39,52 e 76,96 $\mu \mathrm{m}$ enquanto que no sistema

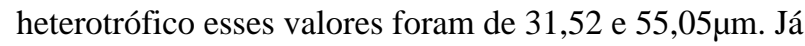
nas plantas aclimatizadas, esses valores foram de 40,32 e $80,71 \mu \mathrm{m}$. A espessura do limbo foliar obtido no sistema sem sacarose e sem vedação foi de $169,06 \mu \mathrm{m}$, no heterotrófico $129,63 \mu \mathrm{m}$ e na condição ex vitro $168,52 \mu \mathrm{m}$ (Figura 1B e 1C).

De acordo com Santos et al. (2005) o aumento da espessura do limbo é resultado da expansão das células do parênquima. Bjorkman (1981) e Nobel (1977) relatam que esse aumento, especialmente pelo alongamento ou adição de células paliçadicas, está relacionado a uma redução na resistência do mesofilo ao dióxido de carbono correlacionado com aumento de fatores potencialmente limitantes à fotossíntese tais como Rubisco, carregadores de elétrons e condutância estomatal. Avaliando as mudanças estruturais que ocorreram nas folhas das plantas cultivadas sem sacarose e sem vedação e comparando-as com as plantas cultivadas ex vitro, verifica-se um prérequisito para a compreensão do processo de aclimatização.

Com exceção da epiderme adaxial, observou-se que as espessuras dos tecidos de plantas, obtidas pelo sistema de cultivo sem sacarose e sem vedação, possuem semelhanças com as ex vitro o que era previsto em virtude do processo em que se desenvolveu. O crescimento fotoautotrófico produziu folhas mais espessas, conferindo maior sustentação e plasticidade e, essa capacidade de alterar a estrutura das folhas em resposta à aeração dos frascos, revela uma capacidade adaptativa, que pode facilitar a aclimatização da espécie.

Resultados semelhantes foram observados por Fideles et al. (2000) realizando comparações anatômicas de plantas cultivadas in vitro e in vivo de Brosimum gaudichaudii Tréc. Os autores verificaram que plantas crescidas in vitro apresentavam-se menos espessas, em razão de um menor desenvolvimento da camada paliçadica, com um aumento do volume de espaços intercelulares. Calvete et al. (2002) caracterizando a morfologia em folhas de morangueiro cultivar Vila Nova, durante o enraizamento in vitro, observaram que as folhas das plantas in vitro apresentam diferenciação no mesofilo, quando comparadas com as folhas de plantas in vivo, mostrando redução do tecido paliçádico e esponjoso assim como decréscimo da camada de cera da cutícula. Kubota \& Tadokoro (1999) também trabalhando com micropropagação fotoautotrófica em tomateiros, verificaram maior vigor das plantas, raízes mais desenvolvidas, folhas mais espessas, e melhor crescimento após a aclimatização, quando comparados às plantas micropropagadas de forma fotomixotrófica.

As plantas cultivadas em meio fotoautotrófico possuíam características semelhantes àquelas mantidas em condições ex vitro, como resposta estomática e presença de cera epicuticular. Essa última deduzida do aspecto brilhante das folhas. Segundo Sutter (1984), a aeração das culturas proporciona melhor formação de cera epicuticular, contribuindo para melhorar a retenção de água. É possível que, por essa razão, as plantas do cultivo fotoautotrófico tenha formado epiderme mais espessa visando à produção de cutina e possibilitando a redução na perda de água. 

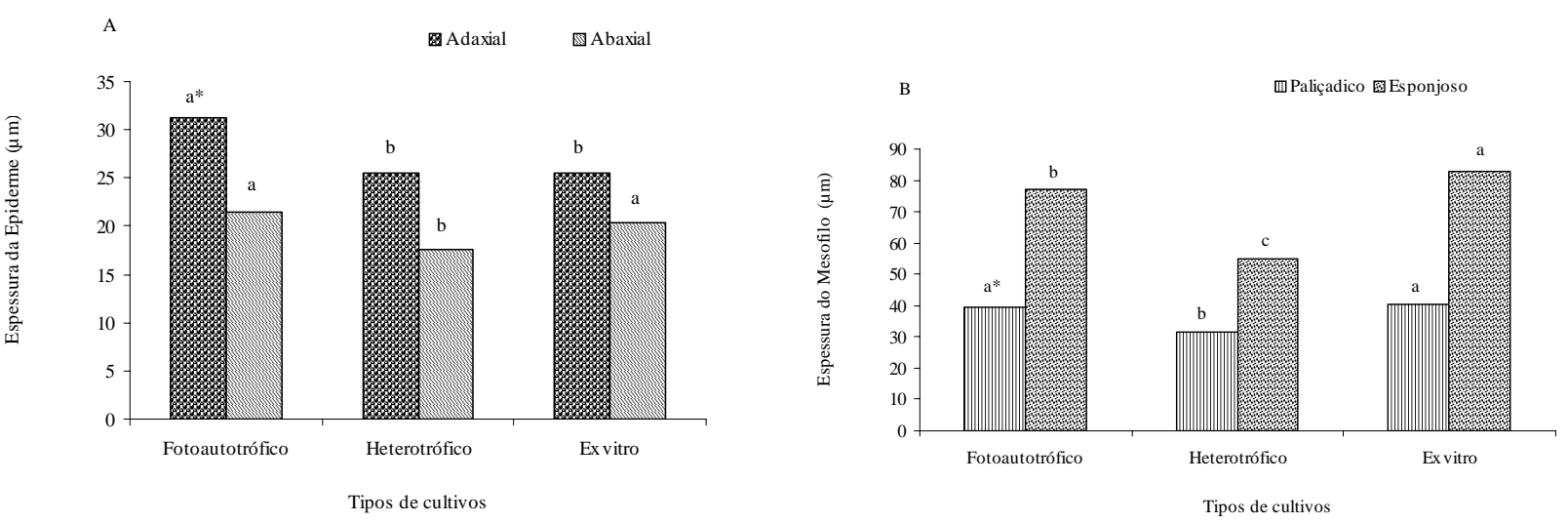

* Médias seguidas de mesma letra não diferem entre si pelo teste de Tukey

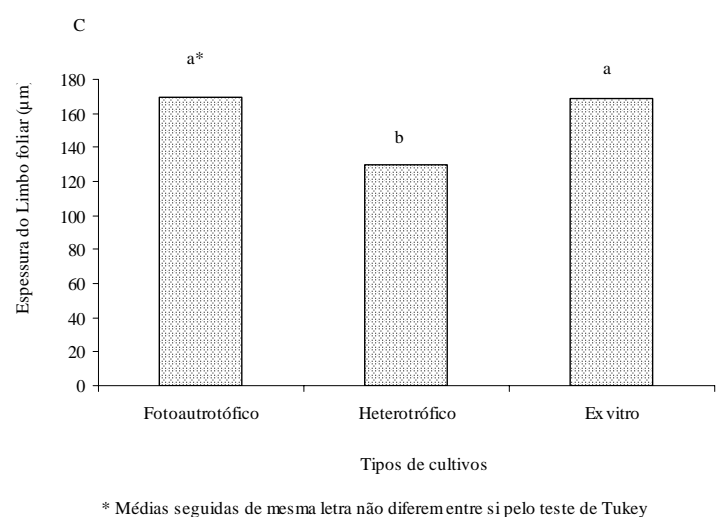

Figura 1 - Espessura de componentes foliares de Annona glabra: (A) da Epiderme, (B) do Mesofilo e, (C) do Limbo foliar. Lavras, MG, 2006.

Quanto ao grau de desenvolvimento da anatomia do mesofilo no limbo foliar, a hipótese é de que no estádio de enraizamento, as plantas de Annona glabra já tinham desenvolvido tecidos fotossintéticos o que permitiu alcançar um balanço hídrico capaz de sustentar o desenvolvimento, aproximando as características das plantas cultivadas fototroficamente daquelas cultivadas ex vitro. Entretanto, é muito importante determinar se o fator crítico, que aumentou o grau de desenvolvimento dos tecidos foliares, foi a rustificação das plantas ou se foi a prevenção de acúmulo de gases tóxicos, principalmente o etileno. Faz-se necessário, portanto, o desenvolvimento de estudos complementares, necessários para comprovar tal hipótese.

As estruturas anatômicas das folhas desenvolvidas durante o enraizamento de A. glabra em condições de estímulo ao fotoautotrofismo in vitro são semelhantes àquelas observadas em condições ex vitro.

\section{REFERÊNCIASBIBLIOGRÁFICAS}

BJORKMAN, O. Responses to different quantum flux densities. In: LANGE, O. L.; NOBEL, P. S.; OSMOND, C. B.; ZIEGLER, H. Encyclopedia of plant physiology new series. Berlin: Springer-Verlag, 1981. p. 57-107.

BUKASTSCH, F. Benerkungren zur doppelfarbung astrablausafranina. Micokosmos, Stuttgart, v. 61, n. 2, p. 255, 1972.

CALVETE, E. O.; KÄMPF, A. N.; SUZIN, M. Concentração de sacarose no enraizamento in vitro de morangueiro. Horticultura Brasileira, Brasília, v. 20, n. 2, jun. 2002. 
KLERK, G. J. de; BRUGGE, J. T.; MARINOVA, S. Effectiveness of indoleacetic acid, indolebutyric acid and naphthaleneacetic acid during adventitious root formation in vitro in Malus “Jork 9". Plant Cell, Tissue and Organ Culture, Dordrecht, v. 49, p. 39-44, 1997.

DONNELLY, D. J.; VIDAVER, W. E.; LEE, K. Y. The anatomy of tissue cultured raspberry prior to and afterr transfer to soil. Plant Cell Tissue Organ Culture, Dordrecht, v. 4, n. 1, p. 43-50, 1985.

FERREIRA, D. F. SISVAR. Versão 4.3. Lavras: DEX/UFLA, 2003.

FIDELIS, I.; CASTRO, E. M. C.; PINTO, J. E. B. P.; GAVILANES, M. L.; SANTIAGO, E. J. A. Características anatômicas de estruturas vegetativas de Brossimum gaudichaudii TRÉC. desenvolvidas in vitro e in vivo. Ciência e Agrotecnologia, Lavras, v. 24, n. 2, p. 327-336, abr./jun. 2000.

FUENTES, G. et al. Exogenous sucrose can decrease in vitro photosynthesis but improve field survival and growth of coconut (Cocos nucifera L.) in vitro plantlets. In Vitro Cellular and Developmental Biology - Plant, New York, v. 41, n. 1, p. 69-76, 2005.

GEORGE, E. F.; SHERRINGTON, P. D. Plant propagation by tissue culture. Eversley: Exegetics, 1984.

GRIBAUDO, I.; FRONDA, A. L'ambientamento delle piante frutticole micropropagate. Rivista di Frutticolture, [S.l.], v. 1, p. 75-79, 1993.

HARARIKA, B. N. Acclimatization of tissue-cultured plants. Current Science, Stamford, v. 85, n. 12, p. 1704-1712, 2003.

KOZAI, T. Micropropagation under photoautotrophic conditions. In: DEBERGH, P. C.; ZIMMERMAN, T. H. Micropropagtion tecnology and application. Dordrecht: Kluwer, 1991. 484 p.

KOZAI, T.; KITAYA, Y. Environmental control for large scale production of in vitro plantlets. In: TERZI, M.; CELLA, R.; FALAVIGNA, A. (Eds.). Current issues in plant molecular and cellular biology. London: Kluwer Academic, 1995. p. 659-667.

KUBOTA, C.; TADOKORO, N. Control of microbial contamination for large-scale photoautotrophic micropropagation. In vitro Cellular and Developmental Biology Plant, New York, v. 35, p. 296-298, 1999.

LEITE, G. B.; FINARDI, N.; FORTES, G. R. L. Efeito de concentrações de sacarose no meio de cultura e da intensidade luminosa no enraizamento in vitro do porta enxerto de Pereira OH x F97. Ciência e Agrotecnologia, Lavras, v. 24, n. 2, p. 335-357, abr./ jun. 2000.

MOHAMMED, D. G.; VIVALDER, W. E. The influence of acclimatization treatment and palntlet morphology on early greenhouse performance of tissue-cultured Douglas fir (Pseudotsuga menziessi (Mirb) Franco). Plant Cell, Tissue and Organ Culture, Dordrecht, v. 21, p. 111-117, 1990.

NOBEL, P. S. Internal leaf area and cellular $\mathrm{CO}_{2}$ resistance: photosynthetic implications of variations with growth conditions and plant species. Physiologia Plantarum, Copenhagen, v. 40, p. 137144, 1977.

SANTOS, L. D. T.; FERREIRA, F. A.; MEIRA, R. M. S. A.; BARROS, N. F.; FERREIRA, L. R.; MACHADO, A. F. L. Crescimento e morfoanatomia foliar de eucalipto sob efeito de deriva do glyphosate. Planta Daninha, Rio de Janeiro, v. 23, n. 1, p. 133-1142, 2005.

SKREBSKY, E. C.; NICOLOSO, F. T.; MALDANER, J. Substrato na aclimatização de Pfaffia glomerata (Spreng) Pedersen produzidas in vitro sob diferentes doses de sacarose. Ciência Rural, Santa Maria, v. 36, n. 5, p. 14161423, set./out. 2006.

SUTTER, E. Chemical composition of epicuticuticular wax in cabbage plant grown in vitro. Canadian Journal of Botany, Ottawa, v. 62, n. 1, p. 74-77, 1984.

WETZSTEIN, H. Y.; SOMMER, H. E.; BROWN, C. L.; VINES, H. M. Anatomical changes in tissue cultured sweet gum leaves during hardening off period. HortScience, Alexandria, v. 16, n. 3, p. 290, June 1981.

ZIV, M. The control of bioreactor environment for plant propagation in liquid culture. Acta Horticulturae, Wageningen, v. 393, p. 25-38, 1986. 